\title{
ENVIRONMENTAL CONTAMINATION WITH PHTHALATES AND ITS IMPACT ON LIVING ORGANISMS
}

\author{
ZANIECZYSZCZENIE ŚRODOWISKA FTALANAMI \\ A ZDROWIE ORGANIZMÓW ŻYWYCH
}

\begin{abstract}
The relevant literature was reviewed to identify phthalate sources in the environment and problems resulting from phthalate contamination of soil and water. Phthalate properties responsible for their toxicity for living organisms were identified, and the effects of phthalates on humans and animals were described. Special emphasis was placed on the effects of exposure to phthalates on human health. Phthalates are readily released into the environment and create a risk of exposure for humans and other living organisms. They are characterized by reproductive toxicity in humans and animals, they can cause infertility and reproductive problems in males. Phthalates are more toxic in young children, which are much more susceptible to phthalate exposure, including fetal life. Phthalates are used in numerous industries, and they are very difficult to eliminate from our daily surroundings.
\end{abstract}

Keywords: phthalates, environmental pollution, plants, animals, humans

\section{Introduction}

The progress of civilization led to introduction of new and improved technologies, consumer goods and products whose manufacture requires new raw materials and new chemical compounds. Many of them are persistent compounds which are not degraded when released to the environment. They are accumulated in the food chain and may be transferred across countries or even continents [1]. Environmental pollutants affect soil properties $[2,3]$ and exert a generally negative influence on flora, fauna and other forms of life $[1,4]$. They can lead to reproductive and endocrinological problems. Selected chemical substances have androgen synthesis [5].

Phthalates, or esters of phthalic acid, are environmental pollutants [6]. Those popular plasticizers are added to polyvinyl chloride to improve its flexibility and hardness. Phthalates are used in nearly every industry, and they can be found in construction materials, printing inks, varnish, latex paint, cosmetics, clothing, food packaging, pharmaceuticals, medical products such as intravenous cannulas, and insecticides [7, 8].

\footnotetext{
${ }^{1}$ Department of Environmental Chemistry, University of Warmia and Mazury, pl. Łódzki 4, 10-727 Olsztyn, Poland

*Corresponding author: miroslaw.wyszkowski@uwm.edu.pl
} 
The objective of this study was to characterize phthalates, to identify sources of phthalate pollution in the environment, and to describe their influence on living organisms.

\section{Phthalate characteristics}

Phthalates are esters of phthalic acid, also known as esters of benzene-1,2-dicarboxylic acid. Phthalates contain a benzene ring with two functional (ester) groups. Their solubility in water decreases with an increase in the length of the carbon chain or molecular weight. Phthalates are oily liquids characterized by high boiling temperature, weak solubility in water and satisfactory solubility in most organic solvents. The analyzed compounds are produced due to an esterification reaction to phthalic acid with various alcohols. Phthalates are classified into two groups: low-molecular-weight phthalates such as di-n-butyl phthalate (DBP) or butyl benzyl phthalate (BBP), and high-molecular-weight phthalates such as diisodecyl phthalate (DIDP) or diisononyl phthalate (DINP) [9].

Phthalates were used as plasticizers for the first time in 1921. Polyvinyl chloride (PVC) modified with phthalates was released for commercial use in 1931. The PVC industry began to develop rapidly in 1950 after the introduction of di(2-ethylhexyl) phthalate [10]. Phthalates are widely used as plasticizers to enhance the flexibility and durability of PVC products. They are added during the manufacture of plastics, cosmetics, printing ink, paper and selected types of packaging [10]. Global phthalate production is estimated at 5 million $\mathrm{Mg}$ per year, of which more than $60 \%$ is used by the processing industries of Japan, North America and Europe [11]. When used as plasticizers, phthalates do not bind permanently with the products to which they are added. They easily migrate to air, water, soil and food. Phthalates are lipophilic, they are readily dissolved and accumulated in lipids $[8,12]$.

The most popular phthalates include di(2-ethylhexyl) phthalate (DEHP), diisodecyl phthalate (DIDP), diisononyl phthalate (DINP) and di-n-butyl phthalate (DBP) [10].

Di(2-ethylhexyl) phthalate (DEHP). DEHP, also known as dioctyl phthalate (DOP), is obtained by the esterification reaction of 2-ethylhexanol with phthalic anhydride [9]. This most popular plasticizer is added to construction materials, consumer goods (rainwear, food packaging, toys), plastics and disposable medical materials such as intravenous cannulas, surgical drains, infusion fluid containers, blood storage and processing containers and blood transfusion equipment [12]. According to Lyche [13], phthalates are ubiquitous in the environment. They were found in soil at the concentration of $0.03-1280 \mathrm{mg} \cdot \mathrm{kg}^{-1}$, in sediments at $0.0003-218 \mathrm{mg} \cdot \mathrm{kg}^{-1}$, drinking water at $0.16-170 \mu \mathrm{g} \cdot \mathrm{dm}^{-3}$, atmospheric air at $<0.4-65 \mathrm{ng} \cdot \mathrm{m}^{-3}$, indoor air at $20-240 \mathrm{ng} \cdot \mathrm{m}^{-3}$, wastewater at $0.0004-58.3 \mathrm{~g} \cdot \mathrm{kg}^{-1}$, and dust at $2.38-4.1 \mathrm{~g} \cdot \mathrm{kg}^{-1}$. DEHP is characterized by high levels of reproductive toxicity, and it can have harmful effects on fertility and may damage the unborn child [14].

Diisodecyl phthalate (DIDP). DIDP is used mainly as a PVC plasticizer. It can be found in various PVC products, including cable jackets, wall panels, flooring, roofing panels, interior car parts and sealants $[15,16]$.

Diisononyl phthalate (DINP). 95\% of globally manufactured DINP is used as PVC plasticizer. It is found in footwear, adhesives, paper products, lubricants, flooring, inks, pigments, sealants, varnish and paint [17]. DINP is produced by the esterification reaction of phthalic anhydride with isononyl alcohol [18].

Di-n-butyl phthalate (DBP). DBP is used mainly as a plasticizer in the production of resins and polymers such as PVC (75\% of DBP output), printing inks, sealants, adhesives, 
glue, fiberglass, cosmetics and nitrocellulose lacquer [19]. DBP is produced by the esterification reaction of phthalic anhydride with n-butanol in the presence of concentrated sulfuric acid. It dissolves easily in most organic solvents, including diethyl ether, acetone, benzene and ethanol [19].

In Regulation (EC) No. 1272/2008 of the European Parliament and the Council of 16 December 2008 on classification, labeling and packaging of substances and mixtures [14], di-n-butyl phthalate was classified as a dangerous environmental substance with toxic effects for the water environment and aqueous organisms. Di-n-butyl phthalate can exert negative effects on reproduction and may damage the unborn child.

In the Regulation of the Minister of Environment of 2010 [20], reference values for selected airborne substances, including bis(2-ehtylhexyl) phthalate, DEHP, DBP, diethyl phthalate (DEP) and dimethyl phthalate (DMP), were set at $100 \mu \mathrm{g} \cdot \mathrm{m}^{-3} \cdot \mathrm{h}^{-1}$ and $15 \mu \mathrm{g} \cdot \mathrm{m}^{-3} \cdot$ year $^{-1}$.

The Directive of the European Parliament and the Council of 2005 [21] banned the use of DEHP, DBP and BBP at concentrations higher than $0.1 \%$ relative to the weight of plasticized material in children's toys and childcare products, and banned the use of DINP, DIDP and di(n-octyl) phthalate (DNOP) at concentrations higher than $0.1 \%$ relative to the weight of plasticized material in children's toys and childcare products that may be placed in the child's mouth.

Pursuant to the provisions of the Regulation of the Minister of Health of 2011 on medical products [22], information that product packaging contains phthalates which are classified as category 1A or 1B mutagens, carcinogens or substances toxic to reproduction in Part 3 of Annex VI to Regulation (EC) No. 1272/2008 of 16 December 2008 [14] must be clearly labeled. The above applies mainly to medical materials intended for the storage and transport of physiological fluids, devices for introducing or evacuating physiological fluids to and from the body, and medicinal products.

The Directive of the European Parliament and of the Council of 2013 [23] introduced DEHP limits for surface waters. The average annual limit value for DEHP in inland waters and other surface waters was defined at $1.3 \mu \mathrm{g} \cdot \mathrm{dm}^{-3}$.

\section{Environmental pollution with phthalates}

Phthalates are applied in the production of many objects of daily use, and their presence has been detected in air, drinking water, rivers, sewage sludge, bottom deposits and soil. Phthalates reach the environment not only during the manufacture of plastics, but also during daily use of the produced goods. They contaminate the environment through leaching, migration and oxidation during product use and storage. Clara et al [24] reported large amounts of phthalates in effluents reaching a wastewater treatment plant and in treated water leaving the plant. In incoming wastewater, DEHP was determined at the concentration of 3.4-34 $\mathrm{ng} \cdot \mathrm{dm}^{-3}$, DEP - at 0.77-9.2 $\mathrm{ng} \cdot \mathrm{dm}^{-3}$ and BBP at $0.31-3.2 \mathrm{ng} \cdot \mathrm{dm}^{-3}$. The phthalates were found in significantly lower concentrations in treated wastewater, but they were not completely eliminated.

Phthalates were also found in sewage sludge. The analyzed compounds migrate to sludge through precipitation in wastewater treatment plants. Phthalates are transmitted to the soil environment when contaminated sludge is used as agricultural fertilizer [25]. Soil can also be polluted with phthalates as a result of oil leakage from agricultural machinery, dry and wet deposition from atmospheric air and, most frequently, the application of 
organic fertilizers. Phthalates reach crop plants from the soil environment. Plants take up soil nutrients together with pollutants, including phthalates, through their root systems. An analysis of agricultural crops revealed the presence of phthalates in every plant organ, from the roots, through the stem, to the seeds [26].

Phthalates are not chemically bonded to materials used in the manufacturing process. They migrate to the surface of the produced goods easily, and then to the environment and living organisms. Phthalates were also found in landfill leachate. The older the landfill, the smaller the amount of leachate, which suggests that phthalates are gradually degraded [27, 28]. However, DEHP was also found in leachate from older landfills, because they was widespread used and slowly degraded [28].

Water runoff from highways and suburban roads was analyzed in Sweden, and phthalates were identified in the collected water samples [24]. DEHP was found in each of the analyzed samples at the concentration of 0.45 to $24 \mu \mathrm{g} \cdot \mathrm{dm}^{-3}$. Phthalates are present in treated effluents and road runoff which contaminates surface waters. The presence of phthalates was also determined in rainwater runoff from Swedish cities: DEHP was identified at the concentration of $1.0-47 \mu \mathrm{g} \cdot \mathrm{dm}^{-3}$, DINP at $<1.0-85 \mu \mathrm{g} \cdot \mathrm{dm}^{-3}$, DIDP at $<1.0-17 \mu \mathrm{g} \cdot \mathrm{dm}^{-3}$ and DNOP at $<0.10-0.16 \mu \mathrm{g} \cdot \mathrm{dm}^{-3}$. Phthalates are widely used in many industries, and they are found in rainwater due to their ability to migrate from the manufactured goods [24].

\section{The influence of phthalates on animals}

It is believed that DBP is responsible for the steady decrease in the number of reptilian species around the world. Even at very small concentrations of 0.1, 0.5, 1.0, 5.0 and $10.0 \mathrm{mg} \cdot \mathrm{kg}^{-1}$, DBP impairs the development internal reproductive organs in animals, leading to underdevelopment of the vas deferens, vacuolization of Sertoli cell cytoplasm, lymphocyte infiltration and gonadal dysgenesis [29].

DEP is characterized by acute toxicity for aqueous organisms, which is expressed by the following LC50 values in $\mathrm{mg} \cdot \mathrm{dm}^{-3}$ of water: Vibrio fisheri bacteria $-11-23 \mathrm{mg} \cdot \mathrm{dm}^{-3}$, Tetrahymena pyriformis protozoa $-7 \mathrm{mg} \cdot \mathrm{dm}^{-3}$, algae: Scenedesmus subspicatus $4.2 \mathrm{mg} \cdot \mathrm{dm}^{-3}$ and Gymnodinium breve $-0.05 \mathrm{mg} \cdot \mathrm{dm}^{-3}$, crustaceans: Daphnia magna $3.9 \mathrm{mg} \cdot \mathrm{dm}^{-3}$, Gammarus pseudolimnaeus - $2.1 \mathrm{mg} \cdot \mathrm{dm}^{-3}$ and Artemia sailna $8 \mathrm{mg} \cdot \mathrm{dm}^{-3}$, insects: Chironimus plumosus - $2.5 \mathrm{mg} \cdot \mathrm{dm}^{-3}$ and Paratanytarsus parthenogenica - $6.3 \mathrm{mg} \cdot \mathrm{dm}^{-3}$, fish: Brachydanio macrochirus - $2.2 \mathrm{mg} \cdot \mathrm{dm}^{-3}$, Oncorthynchus mykiss - $2.3 \mathrm{mg} \cdot \mathrm{dm}^{-3}$, Lepomis macrochirus - $1.5 \mathrm{mg} \cdot \mathrm{dm}^{-3}$, Perca flavescens $-0.35 \mathrm{mg} \cdot \mathrm{dm}^{-3}$, Pimephalis promelas $-1.2 \mathrm{mg} \cdot \mathrm{dm}^{-3}$ and Ictalurus punctatus $1.2 \mathrm{mg} \cdot \mathrm{dm}^{-3}[10]$.

In a study of laboratory rats, phthalates decreased the production of estradiol, a sex hormone responsible for the development of reproductive organs, in females [13]. Exposure to phthalates leads to hormonal and metabolic disorders as well as developmental and reproductive defects resembling testicular dysgenesis in humans [30]. In male rodents, phthalates, mainly DEHP, lower testicular weight, decrease sperm production and contribute to the atrophy of seminiferous tubules, which leads to infertility [9]. In rodents, phthalates can cause kidney, thyroid and liver damage and contribute to liver and spleen cancer $[7,9]$.

In male rats, a prolonged exposure to DEHP led to a more than 50\% increase in the concentrations of testosterone, 17-beta estradiol and luteinizing hormone which is 
responsible for the function of interstitial cells. The proliferation of Leydig cells increased by $40-60 \%$ [29].

\section{The influence of phthalates on humans}

Humans absorb phthalates mainly with contaminated food, but also by inhalation and skin contact. The reference dose (RFD) for humans is $20 \mu \mathrm{g} /(\mathrm{kg} \mathrm{bw} \cdot$ day), and the tolerable daily intake (TDI) has been set at $50 \mu \mathrm{g} /(\mathrm{kg}$ bw $\cdot$ day) [10].

In the work of Lyche [13], DEHP intake with food, expressed in $\mu \mathrm{g} /(\mathrm{kg} \mathrm{bw} \cdot \mathrm{day})$, was as follows: USA: breastfed infants up to the age of 6 months $-7.3 \mu \mathrm{g}$, other groups $-5 \mu \mathrm{g}$, children aged 5-11 years - $18.9 \mu \mathrm{g}$, adolescents aged 12-19 years - $10.0 \mu \mathrm{g}$, adults aged 20-70 years - $8.2 \mu \mathrm{g}$; United Kingdom: infants up to the age of 3 months - $13 \mu \mathrm{g}$, breastfed infants up to the age of 3 months - $21 \mu \mathrm{g}$, children aged 3-12 months - $8 \mu \mathrm{g}$; Germany: subjects aged 14-60 years - 2.5-4.3 $\mu \mathrm{g}$; Denmark: adults - 2.7-4.3 $\mu \mathrm{g}$. The blood concentrations of DEHP metabolites were determined at: USA: newborns - 1.30-6.0 $\mu \mathrm{g}$, pregnant women aged 20-40 years - 1.32-9.32 $\mu \mathrm{g}$, adults aged 20-60 years - 0.7-3.6 $\mu \mathrm{g}$; Germany: children aged 2-14 years - 4.3-15.2 $\mu \mathrm{g}$, students aged 20-29 years - 2.7-6.4 $\mu \mathrm{g}$, subjects aged $14-60$ years $-2.2-7.7 \mu \mathrm{g}$.

Fierens et al [8] identified phthalates in all analyzed food products: fruit and vegetables, milk and dairy products, cereals and cereal products, meat and meat products, fish and fish products, fats and oils. DEHP was the most abundant phthalate, which suggests that humans are at high risk of exposure to this compound.

The presence of phthalates in cosmetics was investigated in a Canadian study. A total of 252 products were analyzed, including 11 hair sprays, 7 hair mousses, 6 hair gels, 18 deodorants, 13 antiperspirants, 20 nail varnishes, 20 body lotions, 20 body creams, 25 baby lotions, 19 baby oils, 31 diaper rash creams, 23 baby shampoos, 30 perfumes and 20 skin cleansing products. Phthalates were found in each product, and the predominant compounds were DEP, DNBP and DEHP. The human body absorbs the analyzed products through the skin [7].

Chinese researchers studied new apartment buildings and discovered phthalates in various rooms, including bedrooms, living rooms and study rooms. They determined DEHP doses inhaled by subjects from various age groups. Children aged up to 6 years were at the greatest risk of inhalation exposure to phthalates due to low body weight and more frequent stay in rooms with high phthalate concentrations in comparison with adults [31]. Small children are more exposed to phthalates because they often place non-consumable objects in the mouth. Breastfed children also ingest phthalates with the mother's milk [32]. Phthalates were identified in urine samples from newborns, which indicates that the analyzed compounds easily cross the placental barrier and pose a threat to unborn children [33]. The available reference literature contains relatively few publications dealing with this problem. Phthalates may have an adverse effect on the growth parameters of a foetus and cause premature labour [34]. Prenatal exposure to DEEP (bis (2-ethoxyethyl) phthalate) has been associated with a low weight at birth; DEP, DNHP (dihexyl phthalate), BBP, DNP (dinonyl phthalate) have been correlated with the abdominal circumference, DEP, DBP, DCHP (dicyclohexyl phthalate), DEHP has been associated with the femure length in female neonates, while DPP and DBEP have been implicated as influencing the length of male newborns. Studies on milk of mothers breastfeeding one month after delivery in 4 cities in Korea indicate the presence of 6 metabolites of phthalates: mono-isobutyl 
phthalate - MiBP, mono-n-butyl phthalate - MnBP, mono(2-ethyl-hexyl) phthalate MEHP, mono-(2-ethyl-5-hydroxyhexyl) phthalate - MEHHP, mono-(2-ethyl-5-oxohexyl) phthalate - DiBP and monoethyl phthalate - MEP [35]. MEB was found in all women's milk samples, MiBP, MnBP and MEHP in 79-89\% of samples while MEHHP and MEOHP (oxygenated forms of DEHP) occurred sporadically. Calculations of the daily consumption led to the conclusion that the reference dose of anti-androgenicity (RfD AA) for DEHP was exceeded in $8 \%$ of infants while excess of the tolerable daily intake (TDI) for di-n-butyl phthalate - DnBP was noted in $6 \%$ of infants. In the study conducted by Guerranti et al [36] in Italy, all human milk samples were detected to contain MEHP, but none had detectable DEHP. However, it needs to be added that the daily intake of MEHP by breastfed infants was below the acceptable threshold. Huang et al [34] claim that the level of DBP in umbilical cord blood was more strongly connected with the body weight at birth than with its content in the venous blood, milk or urine of the mother. Thus, it should be said that considering the low immunity of young organisms (neonates) - it is justifiable to reduce the intake of phthalates with food consumed by breastfeeding mothers.

Contamination with phthalates, and in particular DIBP, DnBP, benzylbutyl phthalate BzBP, DEHP - has also been observed in milk and milk products [11]. Mechanical milking and consumption of phthalate-containing feeds by dairy cattle are the most probable source of this contamination. Research on DMP, DEP, DIBP, DnBP, BBP, DEHP, DCHP and DNOP in 400 food products, completed in Belgium, suggests that DEHP, followed by DnBP and BBP, were the most frequently detected phthalates, although DEHP achieved the highest concentration [8].

In Europe and America, the risk of phthalate exposure was evaluated by numerous expert teams, including the European Chemicals Bureau (ECB), the European Food Safety Authority (EFSA), the European Scientific Committee on Toxicity, Ecotoxicity and the Environment (CSTEE), the US Agency for Toxic Substances and Disease Registry (ATSDR), the Center for the Evaluation of Risks to Human Reproduction (NTPCERHR), the US Environmental Protection Agency and the International Agency on Research on Cancer (IARC). Phthalates are characterized by low acute toxicity $\left(\mathrm{LD}_{50}\right)$ at concentrations of $1-30 \mathrm{~g} / \mathrm{kg}$ bw [12].

Minimal risk levels (MRL), tolerable daily intake (TDI) and no observable adverse effect levels (NOAEL) were determined for various phthalates [7, 12]. MRL values were determined for: DEHP, indirect exposure - $0.1 \mathrm{mg}$, chronic exposure - $0.06 \mathrm{mg}$; DBP $0.5 \mathrm{mg}$; DEP, acute oral exposure - $7 \mathrm{mg}$, chronic oral exposure - $5 \mathrm{mg}$; DNOP, acute oral exposure - $3 \mathrm{mg}$, indirect exposure $-0.4 \mathrm{mg} /(\mathrm{kg} \mathrm{bw} \cdot$ day). TDI values were determined for: DEHP, newborns aged up to 3 months and women of reproductive age $-0.02 \mathrm{mg}$, children aged 3-12 months - 0.025 mg, other subjects - 0.044-0.05 mg; DNOP - $0.37 \mathrm{mg}$; DINP $0.15 \mathrm{mg}$; DIDP - $0.25 \mathrm{mg} /(\mathrm{kg}$ bw $\cdot$ day $)$. NOAEL values were determined at: DEHP 4.8-44 mg, DEP - $750 \mathrm{mg} /(\mathrm{kg}$ bw $\cdot$ day $)$. Interestingly, while the exposure of human populations in the USA and in Germany to DEHP, DBP, BBP and DEHP has been diminishing since 2001, in China, the risk to be exposed to DEHP has risen [37]. Phthalates in a human body are rapidly metabolized to their monoesters (eg MEHP), which can be oxidized and then excreted with urine as MEHP and secondary oxidized metabolites [38].

Ventrice et al [9] observed a correlation between inhalation exposure to phthalates and asthma rates. The results of their study suggest that phthalates, mainly DEHP, can increase the number of inflammatory cells in lungs and bronchial fluid, which can contribute to 
asthma. Exposure to environmental pollutants, including phthalates, was also identified as a possible causative factor behind increasing asthma rates [32].

The prevalence of autism in children increased in the past 20 years [9]. The exact causes of the disease have not been fully elucidated. Autism could result from neurobiological disorders, mainly in fetal life. Autism has a strong genetic basis, which is why the sudden rise in prevalence is surprising. Environmental factors, including phthalates, also contribute to the disease. The concentrations of phthalate metabolites were much higher in autistic 11-year-olds than in their healthy peers [9].

Phthalates have been found to affect estrogen and androgen receptors, whose activity is determined by the length of the phthalate carbon chain [29]. Phthalates can exert a negative effect on androgens in male infants and contribute to health problems in young boys, including hypospadias (abnormal location of the male external urethral orifice on the ventral side of the penis) and reduced distance between the anus and the genitals [41]. Phthalates can impair sperm function by lowering sperm counts and sperm motility, contributing to sperm defects and increasing the prevalence of DNA damage [13]. An experiment involving 1,040 men in China implicated a correlation between the content of phthalates in urine and sperm and the quality of the latter [40]. Out of the eight phthalates analyzed, the strongest correlation was determined for monobutyl phthalate (MBP). Urine and sperm samples with a high MBP content were characterized by a lower sperm volume or total number of spermatozooa. Similar relationships were found for mono-(2-ethylhexyl) phthalate (MEHP) and DEHP. Environmental exposure to DBP and DEHP may lead to inferior quality of semen. According to Cai et al [41], the MBP content was associated with a reduced concentration of spermatozooa, and MBzP (monobenzyl phthalate) with the negative impact on their production. Exposure to DEHP and DBP was correlated with decreased motility of spermatozooa and to MEP or MBzP with a higher risk of DNA damage in spermatozooa. A study involving young male Swedes shows that the level of DEHP metabolites (MEHP, MECPP, MEOHP, MEHHP, MBP) is connected with a lower share of motile and mature spermatozooa [42]. Hence, exposure to DEHP in adulthood can be adverse to male fertility. Testing the concentration of metabolites in urine can provide valuable information, helping to assess the risk of exposure to phthalates in epidemiological environmental research [37]. Phthalates are also linked with increased testis size and lower levels of luteinizing hormone which is responsible for the function of testosterone-producing interstitial cells in the testes. Prolonged exposure to phthalates reduces testosterone production $[13,24]$.

Exposure to low-molecular-weight phthalates, such as DBP, was found to improve motor skills in boys, whereas high-molecular-weight phthalates, such as DEHP, lowered orientation and alertness in girls [43]. Phthalates probably contribute to the risk of endometriosis, a disease in which endometrial cells grow outside the uterine cavity. The analyzed compounds also increase the probability of preterm birth [13]. Phthalates were found to be correlated with early sexual maturation in girls [32]. Phthalates affect insulin resistance and contribute to the risk of diabetes [39].

\section{Conclusions}

Phthalates, the salts and esters of phthalic acid, are ubiquitous in the environment. They are used as plasticizers during the manufacture of PVC, paint, adhesives, cosmetics and food packaging. The discussed compounds are present in every home, and they easily 
migrate to the environment. Phthalates are found in plants, air, soil, water, treated effluents and landfilled waste. They do not bind permanently with the products to which they are added.

Phthalates are readily released into the environment and create a risk of exposure for humans and other living organisms. They are characterized by reproductive toxicity in humans and animals, they can cause infertility and reproductive problems in males. Phthalates are more toxic in young children, which are much more susceptible to phthalate exposure, including fetal life.

Phthalates are used in numerous industries, and they are very difficult to eliminate from our daily surroundings.

\section{References}

[1] Ziółkowska A, Wyszkowski M. Toxicity of petroleum substances to microorganisms and plants. Ecol Chem Eng S. 2010;17(1):73-82. http://tchie.uni.opole.pl/ece_s/S17_1/S1_2010.pdf.

[2] Wyszkowska J, Wyszkowski M. Effect of cadmium and magnesium on microbiological activity in soil. Pol J Environ Stud. 2002;11(5):585-591. http://www.pjoes.com/pdf/11.5/585-591.pdf.

[3] Wyszkowski M, Sivitskaya V. Changes in the content of organic carbon and available forms of macronutrients in soil under the influence of soil contamination with fuel oil and application of different substances. J Elem. 2012;17(1):139-148. DOI: 10.5601/jelem.2012.17.1.12.

[4] Wyszkowski M, Wyszkowska J. The effect of contamination with cadmium on spring barley (Hordeum vulgare L.) and its relationship with the enzymatic activity of soil. Fresen Environ Bull. 2009;18(7):1046-1053.

[5] Adamsson A, Salonen V, Paranko J, Toppari J. Effects of maternal exposure to di-isononylphthalate (DINP) and 1,1-dichloro-2,2-bis(p-chlorophenyl)ethylene (p,p' -DDE)on steroidogenesis is the fetal rat testis and adrenal gland. Reprod Toxicol. 2009;28:66-74. DOI: 10.1016/j.reprotox.2009.03.002.

[6] Grynkiewicz-Bylina B. Dangerous phthalates in children's environment. Ecol Chem Eng S. 2011;18(4):455-463. http://tchie.uni.opole.pl/ece_s/S18_4/S4_2011.pdf.

[7] Koniecki D, Wang R, Moody RP, Zhu J. Phthalates in cosmetics and personal care products: concentrations and possible dermal exposure. Environ Res. 2011;111:329-336. DOI: 10.1016/j.envres.2011.01.013.

[8] Fierens T, Servaes K, Van Holderbeke M, Geerts L, De Henauw S, Sioen I, Vanermen G. Analysis of phthalates in food products and packaging materials sold on the Belgian market. Food Chem Toxicol. 2012;50:2575-2583. DOI: 10.1016/j.fct.2012.04.029.

[9] Ventrice P, Ventrice D, Russo E, De Sarro G. Phthalates: European regulation, chemistry, pharmacokinetic and related toxicity. Environ Toxicol Pharmacol. 2013;36:88-96. DOI: 10.1016/j.etap.2013.03.014.

[10] Peijnenburg WJGM, Sven EJ, Brian F. Phthalates. In: Jørgensen SE, Fath BD, editors. Encyclopedia of Ecology. Oxford: Academic Press; 2008.

[11] Fierens T, Van Holderbeke M, Willems H, De Henauw S, Sioen I. Transfer of eight phthalates through the milk chain - A case study. Environ Int. 2013;51:1-7. DOI: 10.1016/j.envint.2012.10.002.

[12] Heudorf U, Mersch-Sundermann V, Angerer J. Phthalates: Toxicology and exposure. Int J Hyg Envir Heal. 2007;210:623-634. DOI: 10.1016/j.ijheh.2007.07.011.

[13] Lyche J.L. Phthalates. In: Gupta RC, editor. Reproductive and Developmental Toxicology. 2011. http://www.researchgate.net/publication/258257911_Jan_L._Lyche._2011._Phthalates._In_Reproductive_an d_Developmental_Toxicology_Editor._Ramesh_C._Gupta._48_637-655.

[14] Regulation (EC) No 1272/2008 of the European Parliament and of the Council of 16 December 2008 on classification, labelling and packaging of substances and mixtures, amending and repealing Directives 67/548/EEC and 1999/45/EC, and amending Regulation (EC) No 1907/2006. Official Journal of the European Union OJ L 353, 1-2014; 2008. http://eur-lex.europa.eu/legal-content/EN/TXT/ ?uri=celex:32008R1272.

[15] Risk Assessment Report 1,2-benzenedicarboxylic acid, di-C9-11-branched alkyl esters, C10-rich and di-"isodecyl" phthalate (DIDP). Institute for Health and Consumer Protection, European Chemicals Bureau 2003a;36:234. http://echa.europa.eu/documents/10162/b66cca3a-5303-455b-8355-63bf741e263b.

[16] Kransler KM, Bachman AN, McKee RH. Estimates of daily di-isodecyl phthalate (DIDP) intake calculated from urinary biomonitoring data. Regul Toxicol Pharmacol. 2013;65:29-33. DOI: 10.1016/j.yrtph.2012.11.004. 
[17] Hays SM, Aylward LL, Kirman CR, Krishnan K, Nong A. Biomonitoring equivalents for di-isononyl phthalate (DINP). Regul Toxicol Pharmacol. 2011;60:181-188. DOI: 10.1016/j.yrtph.2011.03.013.

[18] Risk Assessment Report 1,2-benzenedicarboxylic acid, di-C8-10-branched alkyl esters, C9-rich and di-"isononyl" phthalate (DINP). Institute for Health and Consumer Protection, European Chemicals Bureau 2003b;35:290. http://echa.europa.eu/documents/10162/0645f0cb-7880-4d23-acea-27b05ed7de39.

[19] Pałaszewska-Tkacz A, Czerczak S. Ftalan dibutylu - frakcja wdychana. Dokumentacja dopuszczalnych wielkości narażenia zawodowego (Di-n-butyl phthalate - inhaled fraction. Occupational exposure limits for phthalates). Podstawy i Metody Oceny Środ Pracy. 2012;73(3):37-70. http://yadda.icm.edu.pl/yadda/ element/bwmeta1.element.baztech-39b11b2c-eea5-4c10-b82f-d4c647536336/c/Palaszewska.pdf.

[20] Rozporządzenie Ministra Środowiska z dnia 26 stycznia 2010 r. w sprawie wartości odniesienia dla niektórych substancji w powietrzu (Regulation of the Minister of the Environment of 26 January 2010 on reference values for selected airborne substances). $\mathrm{DzU} \quad 2010, \mathrm{Nr} \quad 16, \quad$ poz. 87. http://isap.sejm.gov.p1/DetailsServlet?id=WDU20100160087.

[21] Directive 2005/84/EC of the European Parliament and of the Council of 14 December 2005 amending for the 22nd time Council Directive 76/769/EEC on the approximation of the laws, regulations and administrative provisions of the Member States relating to restrictions on the marketing and use of certain dangerous substances and preparations (phthalates in toys and childcare articles) OJ L 344, p. 1-40; 2005. http://eur-lex.europa.eu/legal-content/EN/TXT/?qid=1445256090653\&uri=CELEX:32005L0084.

[22] Rozporządzenie Ministra Zdrowia z dnia 12 stycznia 2011 r. w sprawie wymagań zasadniczych oraz procedur oceny zgodności wyrobów medycznych (Regulation of the Minister of Health of 12 January 2011 on basic requirements and conformance evaluation procedures for medical products). DzU 2011, Nr 16, poz. 74. http://isap.sejm.gov.pl/DetailsServlet?id=WDU20110160074.

[23] Directive 2013/39/EU of the European Parliament and of the Council of 12 August 2013 amending Directives 2000/60/EC and 2008/105/EC as regards priority substances in the field of water policy. OJ L 226, p. 1-17; 2013. http://eur-lex.europa.eu/legal-content/EN/TXT/?uri=celex:32013L0039.

[24] Clara M, Windhofer G, Hartl W, Braun K, Simon M, Gans O, et al. Occurrence of phthalates In surface runoff, untreated and treated wastewater and fate Turing wastewater treatment. Chemosphere. 2010;78:1078-1084. DOI: 10.1016/j.chemosphere.2009.12.052.

[25] Vikelsøe J, Thomsen M, Carlsen L. Phthalates and nonylphenols in profiles of differently dressed soils. Sci Total Environ. 2002;296(1-3):105-116. DOI: 10.1016/S0048-9697(02)00063-3.

[26] Zorníková G, Jarošová A, Hřivna L. Distribution of phthalic acid esters in agricultural plants and soil. Acta Univ Agric Silvic Mendel Brun. 2011;LIX(3):233-238. http://acta.mendelu.cz/media/pdf/ actaun_2011059030233.pdf

[27] Jonsson S, Ejlertsson J, Svensson BH. Transformation of phthalates in Young landfill cells. Waste Manage. 2003;23:641-651. DOI: 10.1016/S0956-053X(03)00099-0.

[28] Kalmykova Y, Björklund K, Strömvall A, Blom L. Partitioning of polycyclic aromatic hydrocarbons, alkylphenols, bisphenol $\mathrm{A}$ and phthalates in landfill leachates and stormwater. Water Res. 2013;47:1317-1328. DOI: 10.1016/j.watres.2012.11.054.

[29] Belowska-Bień K, Zdrojewicz Z. Phthalates - structure, properties, clinical significance. Adv Clin Exp Med. 2006;15(4):677-681. http://www.dbc.wroc.pl/Content/1748/z16.pdf.

[30] Eveillard A, Mselli-Lakhal L, Mogha A, Lasserre F, Polizzi A, Pascussi J, et al. Di-(2-ethylhexyl)-phthalate (DEHP) activates the constitutive androstane receptor (CAR): A novel signaling pathway sensitive to phthalates. Biochem Pharmacol. 2009;77:1735-1746. DOI: 10.1016/j.bcp.2009.02.023.

[31] Pei XQ, Song M, Guo M, Mo FF, Shen XY. Concentration and risk assessment of phthalates present in indor air from newly decorated apartments. Atmos Environ. 2013;68:17-23. DOI: 10.1016/j.atmosenv.2012.11.039.

[32] Mankidy R, Wiseman S, Ma H, Giesy JP. Biological impact of phthalates. Toxicol Lett. 2013;217:50-58. DOI: 10.1016/j.toxlet.2012.11.025.

[33] Enke U, Schleussner E, Pälmke C, Seyfarth L, Koch HM. Phthalate exposure in pregnant women and newborns - The urinary metabolite excretion pattern differs distinctly. Int $\mathrm{J}$ Hyg Environ Heal. 2013;216:735-742. DOI: 10.1016/j.ijheh.2013.01.006.

[34] Huang Y, Li J, Garcia JM, Lin H, Wang Y, Yan P, et al. Phthalate levels in cord blood are associated with preterm delivery and fetal growth parameters in Chinese women. PLoS ONE. 2014;9(2):e87430. DOI: 10.1371/journal.pone.0087430.

[35] Kim S, Lee J, Park J, Kim H-J, Cho G, Kim G-H, et al. Concentrations of phthalate metabolites in breast milk in Korea: Estimating exposure to phthalates and potential risks among breast-fed infants. Sci Total Environ. 2015;508:13-19. DOI: 10.1016/j.scitotenv.2014.11.019.

[36] Guerranti C, Sbordoni I, Fanello EL, Borghini F, Corsi I, Focardi SE. Levels of phthalates in human milk samples from central Italy. Microchem J. 2013;107:178-181. DOI: 10.1016/j.microc.2012.06.014. 
[37] Johns LE, Cooper GS, Galizia A, Meeker JD. Exposure assessment issues in epidemiology studies of phthalates. Environ Internat. 2015;85:27-39. DOI: 10.1016/j.envint.2015.08.005.

[38] Latini G. Monitoring phthalate exposure in humans. Clinica Chimica Acta. 2005;361(1-2):20-29. DOI: 10.1016/j.cccn.2005.05.003.

[39] Dirtu AC, Geens T, Dirinck E, Malarvannam G, Neels H, Van Gaal L, et al. Environ Int. 2013;59:344-353. DOI: 10.1016/j.envint.2013.06.023.

[40] Wang Y-X, You L, Zeng Q, Sun Y, Huang Y-H, Wang Ch, et al. Phthalate exposure and human semen quality: Results from an infertility clinic in China. Environ Res. 2015;142:1-9. DOI: 10.1016/j.envres.2015.06.010.

[41] Cai H, Zheng W, Zheng P, Wang S, Tan H, He G, Qu W. Human urinary/seminal phthalates or their metabolite levels and semen quality: A meta-analysis. Environ Res. 2015;142:486-494. DOI: 10.1016/j.envres.2015.07.008.

[42] Axelsson J, Rylander L, Rignell-Hydbom A, Jönsson BAG, Lindh ChH, Giwercman A. Phthalate exposure and reproductive parameters in young men from the general Swedish population. Environ Internat. 2015;85:54-60. DOI: 10.1016/j.envint.2015.07.005.

[43] Yolton K, Xu Y, Strauss D, Altaye M, Calafat AM, Khoury J. Neurotoxicol Teratol. 2011;33:558-566. DOI: 10.1016/j.ntt.2011.08.003. 